Revista de Estudios Histórico-Jurídicos

[Sección historia del derecho europeo]

XXXVIII (Valparaíso, Chile, 2016)

[pp. 99 - 121]

\title{
O Braço Secular em Portugal na Baixa Idade Média (SÉCUlOS XIII-XV)
}

\author{
[The Secular Arm in Portugal in Late Middle Ages (13th to 15th Centuries)]
}

\author{
José Domingues* \\ Universidade Lusíada-Norte (Porto), Portugal
}

\begin{abstract}
RESUMEN
A ajuda do braço secular prestada pela Justiça régia para se cumprirem as sentenças judiciais ditadas pelo foro eclesiástico surge como um mecanismo de distribuição e equiparação de poderes ao nível do vértice da pirâmide política medieval. Prevista pelo próprio Direito canónico, é compreensível que se tenha alastrado pelo mundo Ocidental, deixando pegadas indeléveis nos vários ordenamentos juspolíticos dos reinos cristãos. Fica aqui uma muito breve e lacunosa aproximação ao que seria este instituto jurídico em Portugal, entre os séculos XIII e XV, para que um dia possa ser aprofundada e, sobretudo, comparada com o que de similar possa ter ocorrido no resto da Europa.

\section{Palabras Clave}

Braço Secular - Igreja - Poder Político - Direito Medieval.
\end{abstract}

\begin{abstract}
The aid of the secular arm, provided by the Regal Justice for the enforcement of judicial sentences dictated by the ecclesiastical forum, arises as a mechanism of regulation and attribution of powers at the level of the vertex of medieval political pyramid. As it was provided by the canon law, it is understandable that it has spread throughout the Western world and left indelible marks in the various legal systems of the Christian kingdoms. It is intended to provide a brief approach to what have been this legal institute in Portugal, between the thirteenth and fifteenth centuries, to allow an enhancement in the future and, above all, to allow a comparison with something similar that have occurred in the rest of Europe.
\end{abstract}

\section{KEYWORDS}

Arm - Church - Political Power Medieval Law.

Recibido el 9 de mayo y aceptado el 5 de julio de 2016

* Doutor em Direito pela Universidade de Santiago de Compostela; Professor na Faculdade de Direito da Universidade Lusíada - Norte (Porto); investigador do CEJEA (Centro de Estudos Jurídicos Económicos e Ambientais). Direcção postal: Rua Dr. Lopo de Carvalho, 4369-006 - Porto (Portugal). Correio electrónico: jdominguesul@hotmail.com. 
"Antre toda las vertudes da Justiça principalmente he achada a execuçam della porque conhecida couza he que pouco aproveitaria a Justiça se nam fosse executada assy nas pessoas como nas cousas julguadas" (AO 3, 93).

\section{INTRODUÇÃO ${ }^{1}$}

O sagrado esteve sempre umbilicalmente ligado ao poder, considerando-se que desde as sociedades humanas mais arcaicas o sagrado terá equivalido a uma forma de exercício do poder. Não surpreende, por isso, que essa arquimilenar tensão latente entre profano e sagrado se mantenha e tenha ficado registada de forma lancinante no adn político da Europa medieval, marcada por uma profunda e arreigada fé em Deus. O reconhecimento do cristianismo como religião oficial veio despoletar a dualidade entre dois poderes: o poder espiritual, representado pelo papa, e o poder temporal, representado pelo imperador.

Sem embargo, o lastro da política medieva no mundo Ocidental acaba por girar -atendendo às coevas e determinadas idiossincrasias, $v . g$., hierocráticas ou anti-hierocráticas, monistas ou dualistas, transmissão descendente ou ascendente do poder, comunicação imediata ou mediata do poder, etc.- em torno da teoria gelasiana dos dois gládios. Terá sido a epístola Duo sunt enviada pelo papa Gelásio I ao imperador Anastácio I, no ano de 494, que abriu caminho à controvérsia entre os dois poderes que governavam o mundo: a autoridade do papa e o poder do imperador ${ }^{2}$. Esta pugna repercutir-se-á, invariavelmente, nas lutas intestinas entre os reis e as respectivas comunidades eclesiásticas de cada um dos seus domínios territoriais, nomeadamente, nos emergentes reinos cristãos da Península Ibérica ${ }^{3}$.

Este estudo, conforme definido em título, limitar-se-á ao espaço geográfico do reino de Portugal, que se desmembrou do reino mater de Leão no curso do

${ }^{1}$ Abreviaturas utilizadas: $\mathrm{OA}=$ Ordenaçoens do Senhor Rey D. Affonso $V$, Real Imprensa da Universidade, Coimbra, 1792 (fac-simile da Fundação Calouste Gulbenkian, Lisboa, 1984/1998); OM-1512 = Ordenaçôes Manuelina: Livros I a V: Reprodução em fac-símile da edição de Valentim Fernandes (Lisboa, 1512-1513), com Introdução de João José Alves Dias, Centro de Estudos Históricos da Universidade Nova de Lisboa (Lisboa, 2002); OM-1521 = Ordenaçoens do Senhor Rey D. Manuel, Coimbra, na Real Imprensa da Universidade, 1797 (fac-simile da Fundação Calouste Gulbenkian, Lisboa, 1984); X = Decretales D. Gregorii Papae $I X$, Svae Integritati, vna cvm glossis restitvtae (Roma, 1582), Corpus Juris Canonici, em http:// digital.library.ucla.edu/canonlaw [consulta 29 abril 2014].

2 Watt, J. A., Pouvoir Spirituel et Pouvoir Temporel, em Histoire de la Pensée Politique Médiévale 350-1450, sous la direction de James Henderson Burns (Paris, 1993) pp. 347-399 (édition originale en langue Anglaise, Cambridge University Press, 1988); UlLmanN, Walter, The Growth of Papal Government in the Middle Ages (2010).

${ }^{3}$ Cfr. o caso paradigmático desenvolvido pelas Partidas de Afonso X de Leão e Castela, que tiveram enorme influência em Portugal, PANATERI, Daniel, Las dos espadas y el vicariato divino en Siete Partidas, em Lemir, 19 (2015) pp. 265-280 
século XII, e a um aspecto muito específico dessa relação nem sempre pacífica, a ajuda do braço secular que o poder civil monárquico empresta à justiça eclesiástica.

No século XII, o reino de Portugal acabou por se tornar independente do reino de Leão sob a égide da Santa Sé, com um juramento de vassalagem e enfeudamento do reino por parte do monarca Fundador, D. Afonso Henriques, que alcança um reconhecimento formal definitivo através da Manifestis probatum (1179) de Alexandre III ${ }^{4}$. A origem do poder político, nestes tempos, parece estar estreitamente ligada ao papado, dando cumprimento ao célebre brocardo de São Paulo: "Non est potestas nisi a Deo" (Romanos XIII.1). Esta estratégia, aliada ao facto de a Península ter sido conquistada aos mouros sem qualquer auxílio do Império, foram decisivos para o não reconhecimento do poder imperial e a afirmação categórica do "rex est imperator in regno suo" ou "rex in regno suo est imperato regni sui” -que é a formulação definitiva tributada a Baldus de Ubaldis- nesta estreita faixa territorial mais a Ocidente ${ }^{5}$.

Os singelos propósitos do compromisso assumido nas laudas que se seguem não incluem a tão ventilada questão da origem e legitimação do poder político, nem sequer a tão ampla relação entre os poderes temporal e espiritual, antes pretendem encarar, numa perspectiva mais restrita e distinta da que é habitual, o relacionamento entre esses dois poderes dominantes -o poder laico e o poder clerical- durante a baixa Idade Média portuguesa. A relação entre o trono e o altar, a Coroa e a Igreja, tem sido considerada, mormente, do ângulo litigioso da disputa pela primazia e do enfrentamento a nível do exercício funcional ${ }^{6}, v . g$,

${ }^{4}$ Cfr. PImenta, Alfredo, A bula "Manifestis Probatum" de Alexandre III, de 23 de Maio de 1179, in Subsídios para a História de Portugal: Textos e Juizos Críticos (Lisboa, 1937) pp. 27-37; 8. ${ }^{\circ}$ Centenário do Reconhecimento de Portugal pela Santa Sé (Bula"Manifestis Probatum" de 23 de Maio de 1179) Comemoração Académica (Lisboa, 1979); Portugal: um estado de direito com oitocentos anos: bula Manifestis probatum de 23 de Maio de 1179 (Lisboa, 1981); CAETANo, Marcello, A Bula Manifestis Probatum (Conferência proferida na Academia Brasileira de Letras Rio de Janeiro, 31-05-1979), in Marcello Caetano no exílio: estudos conferências comunicaçôes (2006), pp. 135-137; Poder Espiritual/Poder Temporal. As relaçôes Igreja-Estado no tempo da Monarquia (1179-1909), Actas do Colóquio, Academia Portuguesa da História (Lisboa, 2009).

${ }^{5}$ Este brocardo tornou-se comum e célebre durante a Baixa Idade Média, espalhando-se por toda a Europa. A sua origem -quer quanto ao espaço territorial, quer quanto ao seu autor- está envolta em alguma polémica, alimentada por figuras ilustres como Calasso, Ercole e Feenstra. Enquanto para uns a primordial manifestação teria sido em França, para outros terá sido em Itália. Este aforismo jurídico serve de cabouca à ideia de potestade (o que a partir de Jean Bodin se convencionou designar por soberania) do rei, tornando-se assíduo desde o século XIII e chamando à colação nomes consagrados de canonistas e civilistas que seria despropositado e demasiado ocioso estar aqui a arrolar. Cfr. a recente exegese de PICARDI, Nicola, La Giurisdizione All'Alba del Terzo Millennio, em Dialletica, Diritto e Processo, 3 (2007) pp. 82-83 -este autor considera o dito aforismo jurídico medieval como a pré-história do conceito moderno de soberania-; para o caso francês veja-se também BABBITT, Susan M., Oresme's Livre de Politiques and the France of Charles V(Philadelphia, 1985) p. 36 (n. 11). Em relação a Portugal, cfr. ALbuquerque, Martim de, Portugal e a "Iurisdictio Imperii", em Revista da Faculdade de Direito de Lisboa, 17 (1964) pp. 303-353; Albuquerque, Ruy de e Albuquerque, Martim de, História do Direito Português (Sintra, 2005), I, pp. 489-500; Silva, Nuno Espinosa Gomes da, História do Direito Português-Fontes de Direito ${ }^{5}$ (Lisboa, 2011) nota final VI.

${ }^{6}$ Carvalho, Joaquim Ramos de, Jurisdição Eclesiástica, em Azevedo, Carlos M. (dir.), 
a eventual hierarquia de fontes preconizada na lei afonsina de $1211^{7}$, a restrição

Dicionário de História da Igreja (Lisboa, 2001), III, pp. 41-43; MARQUES, José, Relaçôes entre a Igreja e o Estado em Portugal no século XV, em Revista da Faculdade de Letras-História, II/1 1 (1994), pp. 137-172; Ventura, Margarida Garcez, Igreja e poder no século XV. Dinastia de Avis e Liberdades Eclesiásticas (1385-1450) (Lisboa, 1997); MARQUES, José, Igreja e Poder Régio, em A génese do Estado Moderno no Portugal Tardo-Medievo: Ciclo de Conferências (Lisboa, 1999), pp. 217-256; BRanco, Maria João, Poder Real e Eclesiástico: A evolução do conceito de soberania e a relação com a praxis política de Sancho I e Afonso II (Tese de Doutoramento em História Medieval apresentada à Universidade Aberta, Lisboa, 2000).

${ }^{7}$ A questão de o fragmento legislativo de Afonso II traduzir ou não a supremacia do Direito canónico trouxe à liça reputados investigadores como Guilherme Braga da Cruz, José Mattoso, Nuno Espinosa Gomes da Silva, Artur Duarte Nogueira e Paulo Otero. Não sendo o momento adequado a uma explanação, ainda que sumária, vide a este propósito as exegeses e identificação dos principais protagonistas em Domingues, José, Exame Crítico às Leis de El-Rei D. Afonso III, em Direito: Revista da Universidade Lusiada do Porto, 7-8 (2013), nota 25; NogueIRA, José Artur Duarte, Lei e Poder Régio I. As Leis de Afonso II (Lisboa, 2006), pp. 243-250 e Silva, Nuno Espinosa Gomes da, História do Direito Português, cit. (n. 4), pp. 183-185 (nota. 2). A esta erudita controvérsia juntou-se recentemente a opinião de outro não menos conceituado protagonista, Paulo Otero, que antevê na lei de Afonso II "uma "nacionalização" da solução jurídica de Graciano". Aspando as palavras do próprio autor, "a lei de D. Afonso II mostra, afinal, a prevalência ou primado do Direito do Estado, segundo resulta da vontade do monarca em autovincular as suas leis ao respeito pelos "direytos da Santa egreia de Roma». Não existe qualquer força jurídica autónoma ou heterovinculativa do Direito Canónico perante o Direito do Estado: o Direito Canónico prevalece por vontade do rei, segundo resulta de uma lei do Estado, enquanto o monarca assim o determinar e sempre nos termos futuros em que ele o fixar". Sem pretensão de melhor arenga, reconhecendo e aceitando o elevado mérito de todos os intervenientes e das suas avalisadas teses e conceituada argumentação, destacando o carácter extremamente sedutor desta última, penso que a laconicidade e as variantes do texto normativo em apreço dão azo às múltiplas interpretações. No meu modesto entendimento estou convicto que desta lei destila apenas um reconhecimento expresso da aplicabilidade do Direito canónico (e garantia dos direitos da Igreja) a par com o Direito civil e o respeito mútuo entre ambos, mas sem pretender estabelecer qualquer hierarquia ou prevalência de um dos ramos do Direito sobre o outro. Este entendimento perdurou desde os primevos tempos da monarquia portuguesa até à Lei da Boa Razão (18 de agosto de 1769), que acabou por remeter a aplicação do Direito canónico apenas para os tribunais eclesiásticos. O "separar das águas" não se confundirá com as assíduas controvérsias que, ao longo desses séculos, estiveram sempre latentes entre os dois poderes em relação à franja de matérias sobreposta a ambos iura, mais difusa e menos consensual. Estas acabariam por ser resolvidas, maioritariamente, de forma pactuada -atente-se, $v \cdot g$., na reacção da Igreja contra a regulamentação unilateral tentada por D. João I através das leis jacobinas de 1419- com recurso a específicos critérios regulamentadores e identificação de caso a caso e nunca por meio de um critério geral de supremacia de um dos Direitos. E muito menos me parece credível, independentemente dos circunstancialismo políticos, o reconhecimento geral da supremacia de um Direito pelo sumo titular do poder antagónico - que aliás, dentro do próprio pecúlio legislativo de Afonso II, acaba por gerar contradições insanáveis-. Duarte Nogueira também duvida da supremacia do ordenamento jurídico da Igreja. $C f$ r. a seguinte bibliografia temática: Otero, Paulo, D. Afonso II e a Edificação do Estado: A raiz do Constitucionalismo Português, em Estudos em Homenagem ao Prof. Doutor Martim de Albuquerque (Coimbra, 2010), II, pp. 523-538 (528-530); NogueIRA, José Duarte, Organização intermédia do Estado - séculos XIII e XIV. Uma perspectiva júris-historiográfica, em Estudos em Homenagem ao Professor Doutor Paulo de Pitta e Cunha (Coimbra, 2010), III, p. 532; MatToso, José, A Cúria Régia de 1211 e o Direito Canónico, in Naquele Tempo. Ensaios de História Medieval, Obras Completas (2000), I, pp. 519-528; Silva, Nuno Espinosa Gomes da, Ainda sobre a lei da Cúria de 1211 respeitante 
à competência legislativa monárquica ${ }^{8}$, a delimitação do privilegium fori ${ }^{9}$, a litis movidas às jurisdições de espaços territoriais ${ }^{10}$, a titulação das jurisdições senhoriais (inclusive eclesiásticas) ${ }^{11}$, o beneplácito régio ${ }^{12}$, etc. Estas temáticas dominam as relações entre os poderes religioso e laico, em Portugal, ao longo de quatro séculos (séc. XII-XV).

Apesar da óbvia e até necessária concorrência entre poderes, estou convicto que o axioma da política medieval portuguesa -à semelhança dos outros reinos da Península- ter-se-á pautado, não tanto por uma unidade fundada na supremacia de um único poder em relação ao outro, mas antes pelo princípio da sociedade dualista, i. e., a sociedade humana a comportar no seu seio duas autoridades, cada uma a disputar a sua supremacia em relação à outra. A superioridade do poder espiritual foi defendida, sem surpresa, por canonistas, teólogos e papas; enquanto o princípio dualista, que nega a plenitudo potestatis do papa, teve do seu lado no-

às relaçôes entre as leis do Reino e o direito canónico, in Direito e Justiça Revista da Faculdade de Direito da Universidade Católica Portuguesa, 12/1 (1998) pp. 3-36; SiLva, Nuno Espinosa Gomes da, Sobre a lei da Cúria de 1211 respeitante às relaçôes entre as leis do Reino e o direito canónico, in Revista Jurídica, 1 (Lisboa, Dez./Maio 1973) pp. 13-19.

${ }^{8}$ Costa, António Domingues de Sousa, Leis atentatórias das liberdades eclesiásticas e o papa Martinho V contrário aos Concílios Gerais, em Biblioteca Pontificii Athenaei Antoniani 19, Studia Historico-Ecclesiastica, Festgabe fur Prof. Luchesuius G. Spattling, O F. M. (Roma, 1977), pp. 505-592; Ventura, Margarida Garcez, As "Leis Jacobinas". Estudo e Transcrição, Medievalista online 12 (2012) [disponível na internet: http://www2.fcsh.unl.pt/iem/medievalista/MEDIEVALISTA12/ventura1203.html].

${ }^{9}$ Ventura, Margarida Garcez, D. Duarte como árbitro do direito de asilo - um caso exemplar, em Actas das III Jornadas Hispano-Portuguesas de Historia Medieval - La Peninsula Ibérica en la Era de los Descubrimientos (1391-1492) (Sevilla, 1991), I, pp. 849-855; DuARTe, Luís Miguel, Casa de Oração ou Covil de Ladrões (Notas sobre o direito de asilo em Portugal durante a Idade Média), em IX Centenário da Dedicação da Sé de Braga, Actas do Congresso Internacional, Vol. II/1 - A Catedral de Braga na História e na Arte (Séculos XII-XIX), Universidade Católica Portuguesa / Faculdade de Teologia - Braga Cabido Metropolitano e Primacial de Braga (Braga, 1990), pp. 617-645.

${ }^{10}$ Costa, Adelaide Pereira Millán da, Comunidades urbanas de senhorio eclesiástico: a divergente experiência da cidade do Porto e de Braga, em Estudos em Homenagem ao Professor Doutor José Marques 1 (Porto, 2006), pp. 77-85; CoElHo, Maria Helena da Cruz, Bispos e Reis: oposições em torno de bens e jurisdiçōes temporais, em Lusitania Sacra, II/15 (Lisboa, 2003), pp. 279-287; Marques, José e CunHA, Maria Cristina Almeida e, Conflito de jurisdiçōes e documentos judiciais: O caso de Braga, em Bracara Augusta 50 (Braga, 2002) pp. 30-31; Marques, José, O Senhorio de Braga, no século XV: principais documentos para o seu estudo, em Bracara Augusta, 46 (Braga, 1997), pp. 5-136; DuARTE, Luís Miguel, Um burgo medieval que muda de senhor. Episódios da vida do Porto medievo, Ler História 5 (Lisboa, 1985), pp. 3-16.

${ }^{11}$ Marques, José, D. Afonso IV e as Jurisdiçōes Senhoriais Galaico-Leonesas no Norte de Portugal, em Brigantia, 12/4 (Bragança, 1992), pp. 175-196; MARQues, José, D. Afonso IV e as Jurisdiçôes Senhoriais, em Actas das II Jornadas Luso-Espanholas de História Medieval (Porto, 1990), IV, pp. 1527-1566; Prata, Jorge, A Jurisdicionalização do Poder: D. Afonso IV e o Chamamento Geral, em Revista de História da Sociedade e Cultura, 13 (Coimbra, 2013), pp. 103-130; PratA, Jorge, Poder e Justiça no Reinado de D. Afonso IV (Dissertação de Mestrado, Faculdade de Letras da Universidade de Coimbra, Coimbra, 2013).

${ }^{12}$ Ventura, Margarida Garcez, Elementos para a compreensão da vigilanncia do rei sobre o seu reino: o beneplácito régio, em Poder Espiritual/Poder Temporal. As relaçôes Igreja-Estado no tempo da Monarquia (1179-1909) (Lisboa, 2009), pp. 429-449. 
mes consagrados como, v. g., o de João Quidort ou João de Paris (1270-1306), Dante Alighieri (1265-1321), Guilherme de Okcham (1288-1347) e Marsílio de Pádua (1280/84-1343).

Sem entrar no debate e na análise argumentativa -repito- em torno dessas polémicas correntes doutrinais da origem e legitimação do poder político: se por um lado, é compreensível o embate entre os dois gladius na disputa pelo poder político e campo jurisdicional de actuação, por outro lado, parece incontestado que a autoridade civil tenha sido instituída para, em sintonia com a autoridade religiosa, punir os malfeitores e honrar os bons -nas palavras de São Pedro, "ad vindictam malefactorum et laudem bonorum" (1 Pedro 2, 14)-. Se foi Deus que instituiu os dois poderes, evidentemente, tencionaria que colaborassem entre si para o bem comum do povo $^{13}$. $\mathrm{Na}$ Península Ibérica desde muito cedo e de forma particular se fez sentir esta ambivalência. "Las interconexiones entre los poderes temporales e espirituales -assevera Teresa Bouzada Gil-ya nacen en la España visigoda con unos tintes de colaboración y mutua ayuda, mientras en los demás reinos de la Europa post-imperial dichas relaciones se movían en la órbita de la supremacia de lo espiritual [...] En España, la colaboración entre las dos potestades se mantiene a lo largo de todo el Medievo" ${ }^{\prime 4}$.

Em Portugal, é o próprio monarca D. João I que, em documento de 12 de Janeiro de 1408, consignou que " a Justiça sagral deue d ajudar a cresiastica pera cumprir djreito e Justiça quando pera ello for requerido" 15 e na concórdia com o clero de 1427, deixou recomendado que "huma jurdiçom deve seer ajudada pela outras [...] huum braço deve d'ajudar ho outro" (OA 2, 7, 60). Diogo Lopes Rebelo, na sua De Republica Gubernanda per Regem, deixa bem claro que os bispos "quando não poderem, por causa da soberba e insolência de alguns rebeldes das suas dioceses, trazê-los com o báculo ao caminho da verdade e aos preceitos de Jesus Cristo, nosso Salvador, utilizem o auxílio do braço secular" ${ }^{16}$. Este ideal de entreajuda entronca numa passagem oriunda de Santo Isidoro de Sevilha, quando afirma expressamente que "os principes seculares conservam dentro da Igreja as honras de potestade recebidas para defenderem a disciplina eclesiástica; tais potestades seriam inecessárias se não fosse para imporem com o terror da disciplina (pela força) o que o bispo não

13 Sobre as relações de cooperação entre os dois poderes, $c f r$. CaRvalHo, Joaquim Ramos de, Jurisdição Eclesiástica, cit. (n. 5), p. 42. Realçando os casos de foro misto e da ajuda do braço secular, "essa cumplicidade -complementa Ramos de Carvalho-assume formas que se cristalizam em mecanismos jurídicos: o direito secular incorpora como suas algumas normativas do direito canónico, tribunais eclesiásticos (como a Inquisição) são criados por iniciativa régia, os juizes eclesiásticos delegam a execução de determinadas penas nos tribunais seculares, a alta hierarquia eclesiástica ocupa lugares importantes do aparelho jurídico do Estado".

14 Bouzada Gil, Maria Teresa, La Vía de Fuerza: La Prática en la Real Audiencia del Reino de Galicia (Siglos XVII-XVIII) (Santiago de Compostela, 2001), pp. 17-18.

15 Chancelarias Portuguesas. D. João I, vol. III, tomo 2 (Lisboa, 2006), doc. III-467, pp. 37-38.

16 Do Governo da República pelo Rei: De Republica Gubernanda per Regem / Tratado das Produçóes das Pessoas [Divinas]: Tractatus de Productionibus Personarum [In Divinis], fac-simile das ediçôes de Paris de fins do séc. XV, Versão em português de Miguel Pinto de Meneses, com um estudo de Manuel Cadafaz de Matos (Lisboa, 2000), p. 133. 
pode alcançar por meio do ensino e do discurso" (Sentenças III, 51, 4). Vai ser este instituto jurídico da ajuda do braço secular, prestada ao braço eclesiástico, o objecto deste trabalho e que vai ocupar as linhas que seguem.

\section{O Braço Secular em Portugal}

Um eficaz mecanismo medievo de cooperação entre os dois poderes foi vertido para o chamado auxílio do braço secular, solicitado pelo poder eclesiástico ao poder laical para conseguir impor as suas decisōes jurisdicionais e, sobretudo, as correspondentes sanções coactivas de sangue. A ajuda do braço secular, que terá funcionado como um mediador jurídico-político entre Estado e Igreja na Baixa Idade Média portuguesa, serviu de mote às breves linhas que se seguem. De salientar que na ordenação de D. Fernando, de 18 de Setembro de 1368, ficou explícito que "a todo Rey cathollico como braço da Santa eigreia perteeçe de fazer e mandar comprir e aguardar as suas sentenças que direitamente som dadas $E$ fazer que os seos sujectos seiam obedientes a ellas nos casos que som de sua jurdiçom" (OA 5, 27, 3) ${ }^{17}$.

Este apoio jurídico de el-rei já vinha de tempos muito anteriores e estava bem arraigado em Portugal no século XIII, pelo menos, como deixa antever a queixa eclesiástica apresentada às Cortes reunidas em Guimarães no ano de 1250: "Primus igitur articulus continebat quod cum nos teneamur ad exequendas sentencias episcopi licet ad hoc potestas nostra inuocetur tanquam brachium secularem non solum illud recusamus facere, sed etiam impedimus quod sentencie episcopi non sint modo aliquo fructuose. Respondemus espiscopi sentencias semper defendimus et in posterum defendemus nec earum executionem prohibebimus nec impediemus quin fructum et efficaciam consequatur" 18 .

Mas o auxílio do braço secular nunca esteve limitado apenas ao ordenamento jurídico luso ${ }^{19}$ e já vinha, de longa data ${ }^{20}$, previsto pelo próprio Ius canonicum, v. g., no Decreto de Graciano (C.23 q.5 c.20) (C.23 q.4 c.39), nas Decretais de Gregório IX (X 5, 40, 27) (X 1, 31, 1) e no Livro Sexto (VIo 5, 2, 18). O que fez com que, não raro, fosse o próprio Sumo Pontífice a chamar à colação a obrigação de os reis prestarem auxílio secular ao clero do seu reino ${ }^{21}, v$.g., Gregório IX, por

17 Braga, AD - Colecção Cronológica, doc. 902; Braga, AD - Rerum Memorabilium, vol. 3, fl. 89. Esta lei acabou por ser compilada na colectânea oficial de Ordenações terminada no reinado de D. Afonso V (Ordenaçôes Afonsinas), donde se cita.

${ }^{18}$ Herculano, Alexandre, Portugalliae Monumenta Historica: A saeculo octavo post christum usque ad quintumdecimum - Leges et Consuetudines, vol. 1 fasc. 2 (Lisboa, 1858), p. 188.

19 Para o caso de Inglaterra, LogAn, F. Donald, Excommunication and the Secular Arm in Medieval England, Studies and Texts 15 (Toronto, 1968).

${ }^{20} \mathrm{~V} . \mathrm{g}$. " "c'est en 1022 que le bras séculier sévit pour la première fois en France contre l'hérésie", Havet, Julien, L'Hérésie et le Bras Séculier au Moyen Âge Jusqu'au XIII' Siècle (Paris, 1881) p. 12 [disponível na internet: http://gallica.bnf.fr/ark:/12148/bpt6k66940c.r=.langPT].

${ }^{21}$ Álvaro Pais, firmado nos preceitos do Ius canonicum, assegura que os reis, quando invocados pelos juízes eclesiásticos, são obrigados a prestar-lhe auxílio e favor, sob pena de serem depostos da sua dignidade se indevidamente o recusassem -PAIS, Álvaro, Espelho dos Reis I, Estabelecimento do texto e tradução do Dr. Miguel Pinto de Meneses (Lisboa, 1955, pp. 258-259-. Neste sentido, chamando à colação esta e outras passagens do referido autor, 
documento de 28 de Novembro de 1234, recomenda a D. Sancho II o dever de protecção ao arcebispo de Braga e de obrigar a prestar contas certo leigo que disso fora dispensado pelo antecessor, sem consentimento do cabido ${ }^{22}$; o mesmo Papa, em documento de 4 de Junho de 1238, repreende D. Sancho II pelos agravos infligidos aos sequazes do deão de Lisboa, ameaçando recorrer ao poder secular, se não reparar os males e os proteger contra as arremetidas dos inimigos ${ }^{23}$; uma bula do de Calixto III, de 1457, recomenda a D. Afonso V que auxilie com braço secular o arcebispo de Braga, D. Fernando da Guerra, contra o duque de Bragança $^{24}$; uma carta do mesmo D. Afonso V, datada de 8 de Fevereiro de 1476, faz referência a uma sentença da Corte de Roma que impunha, caso necessário, $o$ recurso à ajuda do braço secular a prestar ao arcebispo de Braga na sua execução ${ }^{25}$.

Aliás, o fundamento legal da ajuda do braço secular surge expressamente tributário do supra referido fragmento normativo do Decreto de Graciano - " $E$ assy diz huum degredo que se começa príncipes que he em na xxiiija ca. q . v" (C.23 q. 5 c.20)- em lei, sem data, do tempo de el-rei D. Dinis (1279-1325) ${ }^{26}$. Nesse acto legislativo dionisino, um dos casos em que os clérigos são considerados de jurisdição régia e deveriam responder perante juiz leigo traduz e define objectivamente o instituto jurídico em causa. Aspando o Português da época, diz assim: "Se o bispo dá sentenças algumas contra alguuns creligos ou contra lleigos E nom as pode auer conpridas sse o bispo chamar el Rey come braço sagrall el Rey pode E deue conprir as ditas sentenças outrosy se for chamado come braço sagrall pollo bispo pera alçar força deue E pode-a alçar atam bem dos leigos como dos créligos" 27.

Aliando este lacónico enunciado legislativo a um escasso punhado de registos escritos resgatados à rasoira do tempo, a título muito sumaríssimo, fica uma breve análise do instituto jurídico sub judice, tentando-o dissecar quanto à sua (III) legitimidade processual, (IV) âmbito material e (V) efeitos jurídicos. O procedimento judicial no seio do supremo tribunal da Corte, iniciado com um pedido do poder eclesiástico -a carta de chamamento de ajuda de braço sagral-, dispensa análise de minúcia uma vez que correria os termos de um processo comum -com os pormenores inferidos por José Marques, a partir da análise à sentença de 18 de Maio de $1458^{28}-, v$. g., pedido feito por prelado ou seu vigário geral, acompanhado da

cfr. MARQUES, José, O recurso à justiça secular no século XV: um caso paradigmático, em Scientia Iuridica, LIV/301 (2005), pp. 91-94.

22 Costa, António Domingues Sousa, Mestre Silvestre e Mestre Vicente - Juristas da contenda entre Afonso II e as suas irmãs (Braga, 1963), p. 365, nota 475.

${ }_{23}$ Costa, António Domingues Sousa, Mestre Silvestre e Mestre Vicente, cit. (n. 21), pp. 260-261, nota 386.

${ }^{24}$ Marques, José, O recurso à justiça secular no século XV, cit. (n. 20), p. 97.

25 Braga, AD - Colecção Cronológica, doc. 1367. O pergaminho está em muito mau estado e parcialmente destruído, pelo que esta informação foi retirada do resumo em apenso, lavrado em época muito posterior.

${ }^{26}$ Este fragmento vai servir de suporte a um parágrafo da Reforma das Ordenaçôes de 1446 (OA 3, 15, 44).

27 Ordenações de D. Duarte, edição preparada por Martim de Albuquerque e Eduardo Borges Nunes (Lisboa, 1988), p. 274.

${ }^{28}$ MARQues, José, O recurso à justiça secular no século XV, cit. (n. 20), pp. 99-103. A carta 
subida do processo tramitado pelas justiças eclesiásticas, observância do princípio do contraditório, do princípio da fundamentação, análise do mérito da acção e decisão final, com outorga ou não da correspondente carta de ajuda do braço secular a apresentar, para execução definitiva, perante as justiças civis do reino.

\section{Legitimidade Processual}

Sem embargo de melhor arenga e tendo em linha de conta a elevada míngua documental, no espaço temporal em que se situa e limita este trabalho (séculos XIII a XV), as legitimidades processuais parecem estar reservadas à cúspide de cada um dos poderes: a legitimidade processual activa aos prelados e a legitimidade processual passiva ao monarca. O que quer dizer que, em princípio, só os prelados e seus vigários gerais podiam solicitar a ajuda do braço secular, que faria parte da Justiça maior reservada ao monarca e, por isso, só por ele poderia ser concedida. É este o princípio que subjaz ao supra aspado - "sse o bispo chamar el Rey come braço sagrall' - preceito normativo de D. Dinis.

A fim de demarcar a posição do monarca e atalhar a eventuais abusos, o corregedor régio de Entre-Douro-e-Minho, Afonso Domingues, por instrumento outorgado em Rates, no dia 15 de Junho de 1342, a propósito da demarcação entre o foro civil e o religioso, deixa bem claro que as justiças das terras só deviam prestar o auxílio do braço secular mediante apresentação de carta ou mandado de el-rei ou do seu corregedor de comarca, sob pena de pagarem em dobro os danos e perdas causados aos executados e de serem presos por ofensa à Justiça maior de el-rei. Consequentemente, ao arcebispo e bispos -bem como aos seus vigários, juízes e ouvidores- ficava vedado o pedido directo para as justiças civis das terras (juízes e alcaides) ${ }^{29}$.

E mesmo os corregedores de comarca-apesar de serem magistrados superiores e os representantes imediatos do rei junto das populaçôes- precisariam de uma delegação expressa do monarca para poderem conceder a ajuda do braço secular, uma vez que nos sucessivos regimentos -1332, 1340, 1361 e 1418; agregados,

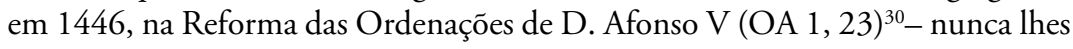
foi consagrada tal prerrogativa. Assim se compreende que, $v$. g., no regimento do desembargador enviado com alçada à comarca da Beira, outorgado em Montemoro-Novo no dia 30 de Dezembro de 1495, lhe seja delegada essa legitimidade e competência - "Item. vos damos poder e autoridade seendo vos requerido pollos prelados das dictas comarquas ou per quaaeesquer outras justiças ecllesiasticas que lhes dees ajuda de brraço sagrall contra os que pesuuee [m] e acupam as igrejas e beneficios e cousas ecllesiasticas como nom devem. Vos lhe darees a dicta ajuda de brraço sagrrall segundo se custuma dar na nosa Casa da Sopricaçam" ${ }^{31}$-, que, pouco tempo depois,

de ajuda do braço secular foi concedida à revelia do abade Gonçalo Domingues, ex vi do costume e estilo da Corte.

29 Braga, AD - Colecção Cronológica, doc. 755.

${ }^{30}$ Domingues, José, As Ordenaçôes Afonsinas - Três Séculos de Direito medieval (1211-1512) (Sintra, 2008), pp. 245-271.

${ }^{31}$ Lisboa, IAN/TT - Gaveta 20, mç. 10, doc. 11; DuARTE, Luís Miguel, Justiça e Crimina- 
foi expressamente subtraída ao homólogo Pedro Gouveia, enviado com alçada à comarca de Entre-Douro-e-Minho por carta de 8 de Julho de 1497 -"e quanto a ajuda de braço sagrall havemos por bem que nom dees nenhuua, porquanto ho dar da dicta ajuda em espiciall he resarvada a nossa pessoa e a nossa Cassa da Sobpricaçom"32-.

Presumivelmente, neste enquadramento legal de delegação de competências deve ser inserida, $v$. g., a petição que o cónego e vigário geral de Braga, Lourenço Afonso, no dia 12 de Julho de 1410, dirigiu ao coetâneo corregedor de EntreDouro-e-Minho, Gonçalo Vasques Vieira, para o auxiliar com o braço secular contra Pedro Martins, que andava excomungado por não pagar ao cabido de Braga as pensôes da quinta de Matamâa ${ }^{33}$; a súplica dos juízes e executores apostólicos -o bispo D. Gil e D. Gonçalo, abade do mosteiro de Tibães (c. Braga)- escrita em Braga no dia 5 de Março de 1473, dirigida a Vasco Pereira, ouvidor do regedor da justiça em Entre-Douro-e-Minho, Vasco Martins de Resende, em que lhe pede ajuda do braço secular contra o excomungado Diogo Ferreira ${ }^{34}$; ou o pedido de ajuda do braço secular dirigido por Pedro Afonso ao coevo corregedor de Trás-osMontes, Diogo Afonso, para que lhe conferisse a posse da igreja de São João de Ansiães, tomada à força por Lopo Vasques de São Paio e seus homens, conforme relato em carta régia de 7 de Maio de 1420 , outorgada em santarém por D. João I ${ }^{35}$.

Ou será que estes magistrados eram meros intermediários para se fazer chegar o pedido ao tribunal superior do reino?

Em relação aos antecessores dos corregedores das comarcas, os meirinhosmores de Afonso III e D. Dinis, fica a mera suspeita de que poderiam agir como auxílio de braço secular, mesmo sem a prévia autorização régia $-v$. g., a sentença de mestre Domingos, tesoureiro da Sé do Porto e ouvidor no pleito dos padroeiros da igreja de $S$. Fins e o mosteiro de Moreira parece ter ido para execução imediata ao meirinho-mor de Aquém-Douro, Estêvão Peres, que a remeteu para execução ao seu meirinho em Santa Maria da Feira, Martim Soares, conforme documento lavrado por este último no dia 6 de Novembro de $1293^{36}$; a carta precatória de Estêvão Anes, arcediago de Neiva, e Gonçalo Esteves, ambos vigários gerais de Braga, dirigida, no dia 5 de Maio de 1312, a D. Fernando Rodrigues, meirinhomor de Entre-Douro-e-Minho, em que lhe pede auxílio do braço secular para ser conservado Aires Pais, abade da igreja de Argivai (c. Póvoa de Varzim), na posse

lidade no Portugal Medievo (1459-1481) (Coimbra, 1999), doc. 93, pp. 636-646.

32 Porto, AHM - Vereaçôes, Livro 6, fls. 201-202; Figueiredo, Maria Amélia da Silva Alves dos Santos, A Administração Municipal do Porto entre 1488 e 1498 Segundo o Livro 6 de Vereações, Dissertação de Mestrado em História Medieval apresentada à Faculdade de Letras da Universidade do Porto (Porto, 1996), doc. 6, pp. 185-186 [disponível na internet: http:// repositorio-aberto.up.pt/handle/10216/18123].

33 Braga, AD - Gaveta 2a das Propriedades do Cabido, doc. 48.

${ }^{34}$ Braga, AD - Gaveta 2a das Propriedades do Cabido, doc. 76.

35 Braga, AD - Colecção Cronológica, doc. 1015.

36 Censual do Cabido da Sé do Porto - Códice membranáceo existente na Biblioteca do Porto, edição de Joaquim Grave (Porto, 1924), p. 220. Cfr. a carta concedida por este meirinho régio, no dia seguinte, ao prior e convento de Moreira, publicada em Martins, Ana Maria, Documentos Portugueses do Noroeste e da Região de Lisboa. Da Produção Primitiva ao Século XVI (Lisboa, 2001), doc. 28, p. 153. 
do padroado das cavalarias, comeduras e outras pertenças da dita igreja que lhe demandava o cavaleiro Fernão Gonçalves ${ }^{37}$.

Em finais do século XV a reserva em prol da Justiça maior de el-rei saiu reforçada quando D. João II, em Évora, no dia 4 de Fevereiro de 1490, proibiu os magistrados da Casa do Cível -apesar de estarem em posse de conhecer sobre esta matéria, conforme constava explícito no seu regimento- de tomarem conhecimento dos feitos de ajuda do braço secular, que passaria a ser determinada apenas na Corte, através do tribunal supremo da Casa da Suplicação. Querendo sanar certas injustiças derivadas da arbitrariedade que se verificava na autorização das ajudas do braço secular, o Príncipe Perfeito decide que "daqui em diamte as ajudas de braço sagrall se peçam soomente em nossa corte e cassa da Sopricaçam aos nossos desembargadores do paaço", que acompanhavam o monarca e, por isso, mais facilmente podiam colocar-lhe eventuais dúvidas daí resultantes. Todos os processos pendentes, ainda a correr termos na Casa do Cível, deviam ser de imediato enviados à Corte cerrados e selados, no ponto e estado em que estivessem, e às partes assinado termo para comparecerem a Direito perante os desembargadores da Casa da Suplicação ${ }^{38}$.

Esta prerrogativa reservada aos desembargadores da Casa da Suplicação passou a constar no seu regimento, desde a primeira impressão das Ordenaçôes Manuelinas: "Item daram ajuda de braço segral. em relaçam [citadas as partes]" visto o processo e achando que foy ordenadamente feito. a qual ajuda de braço segral nom se dara na casa do ciuil. nem em outra alguma parte se nom em nossa casa da suplicaçam.

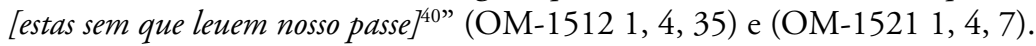

Neste sentido, não admira que grande parte dos documentos ${ }^{41}$ estabeleçam uma relação ao nível do topo da hierarquia do poder eclesiástico com o sumo representante do poder estadual: (i) os dois pedidos de ajuda do braço secular feitos -um a 23 de Novembro de 1302 e outra a 18 de Março de 1304-pelo bispo de Lisboa, D. João, a el-rei D. Dinis, contra o carpinteiro Miguel Lourenço que

37 Braga, AD - Livro das Cadeias, doc. 69. Ter-se-á em conta a título exemplificativo que -embora não refira expressamente o braço secular- a sentença dada pelo juiz eclesiástico na contenda sobre a igreja de S. Félix da Marinha (c. Vila Nova de Gaia) é mandada executar por el-rei D. Dinis, por documento de 3 de Dezembro de 1393, ao seu meirinho-mor de Aquém-Douro, Estêvão Peres (Censual do Cabido da Sé do Porto, cit. (n. 35), pp. 222-223; MatToso, José, Krus, Luís e Andrade, Amélia, A Terra de Santa Maria no Século XIII - Problemas e Documentos, edição da Comissão de Vigilância do Castelo de Santa Maria da Feira (1993), doc. 111, pp. 281-282.).

${ }^{38}$ Lisboa, IAN/TT - Feitos Findos, Casa da Suplicação, Liv. 1, fls. 54v-55v; publicado em Fragmentos de legislação escritos no livro chamado Antigo das Posses da Casa da Supplicação, em Collecção de Livros Ineditos de Historia Portugueza, dos reinados de D. João I, D. Duarte, D. Affonso Ve D. João II, publicados de ordem da Academia Real das Ciências de Lisboa, por José Correia da Serra (Lisboa, 1793), III, n. ${ }^{\circ}$ 26, pp. 574-576; Lisboa, IAN/TT - Feitos Findos, Casa da Suplicação, liv. 72, fl. 76v (Livro das Leis Extravagantes).

39 Acrescento da edição de 1521.

40 Falta na edição de 1521.

${ }^{41}$ Limito-me apenas aos documentos que expressamente fazem referência ao «braço secular», porque muitos outros existem que, mesmo não o referindo expressamente, se podem inserir no seu âmbito material. 
andava excomungado ${ }^{42}$; (ii) o arcebispo e cabido de Braga, por instrumento de 22 de Fevereiro de 1323, dirigem-se a D. Dinis e ao infante D. Afonso para que, como braço secular, lhe enviem alguém para fazer Justiça em Entre-Douro-e-Minho ${ }^{43}$; (iii) Gonçalo Miguéis, tesoureiro da Sé de Lamego, na qualidade de juiz delegado da Sé Apostólica, no dia 15 de Janeiro de 1355, solicita a D. Afonso IV o apoio do braço secular para fazer cumprir a sentença que tinha proferido na questão entre o bispo de Cidade Rodrigo e o mosteiro de Santa Maria de Aguiar (c. Figueira de Castelo Rodrigo ${ }^{44}$; (iv) o arcebispo de Lisboa, D. João, solicitou a el-rei que "por mercee como em ajuda de braço sagral" obrigasse os tabeliães, juízes e justiças dos seus bispados sufragâneos de Évora, Silves, Guarda e Lamego a publicar e cumprir as suas sentenças -D. João I acedeu ao pedido por carta de 12 de Janeiro de 1408, passada em Estremoz- ${ }^{45}$; $(v)$ D. João I, por instrumento outorgado em Évora no dia 24 de Abril de 1421, concede uma ajuda em geral do braço secular ao arcebispo de Lisboa D. Diogo e seus vigários ${ }^{46}$ (vi) esta ajuda genérica foi repetida no reinado do monarca sucessor, D. Duarte, ao contemporâneo arcebispo de Lisboa D. Pedro e seus vigários, por instrumento outorgado em Santarém no dia 15 de Dezembro de $1434^{47}$; (vii) el-rei D. Afonso V, no dia 18 de Maio de 1458, concede a ajuda do braço secular contra Gonçalo Domingues, que à força e contra o Direito canónico ocupava a igreja de S. Miguel de Tresmiras (c. Vila Pouca de Aguiar) e impedia o novo pároco, Vasco Pires, de ocupar o cargo para que tinha sido confirmado pelo arcebispo de Braga, D. Fernando da Guerra ${ }^{48}$.

Quanto à legitimidade processual activa eclesiástica, o que os documentos consultados permitem inferir é uma plausível reserva a favor dos bispos e arcebispos, que a delegavam nos vigários gerais, ex vi do seu regimento ${ }^{49}$. Nada obstando a que essa competência também pudesse ser delegada em outra pessoa, $v . g$., D.

42 Braga, AD - Gaveta de Notícias Várias, doc. 76. Referido por LineHAN, Peter, Two Marriage Cases from Medieval Iberia, em Zeitschrift der Savigny-Stiftung für Rechtsgeschichte. Kanonistische Abteilung, 83 (1997), p. 337 nota 16.

43 Braga, AD - Rerum Memorabilium, vol. II, fls. 33v-34v; Domingues, José, Dos Meirinhados às Comarcas Medievais Portuguesas, em Initium, 14 (2009), pp. 233-235.

${ }^{44}$ Lisboa, IAN/TT - Mosteiro de Santa Maria de Aguiar da Beira, mç. 3, doc. 33; SARAIVA, Anísio Miguel Sousa, A Sé de Lamego na Primeira Metade do Século XIV (1296-1349) (2003), doc. 37 , pp. $875-876$.

45 Chancelarias Portuguesas. D. João I (Lisboa, 2006), vol. III, tomo 2, doc. III-467, pp. 37-38.

46 Chancelarias Portuguesas. D. João I (Lisboa, 2006), vol. IV, tomo 1, doc. IV-141, pp. 91-92.

47 Chancelarias Portuguesas. D. Duarte (Lisboa, 1998), vol. I, Tomo 1, doc. 253, pp. 92-93.

${ }^{48}$ Marques, José, $O$ recurso à justiça secular no século XV, cit. (n. 20), pp. 104-108.

49 V.g., no impresso Regimento dos Oficiais do Auditório de Coimbra: "Item neste auditorio se acostuma que depoys de ser hum excomungado e declarado ate de participantes, como a igreja nam tem outras armas para proceder, andam excomungados em perjuyzo de suas almas. Por ho qual mandamos ao dito vigayro que depoys da carta de participantes remeta a execuçam da sentença ao juyz secular, requerendo ho aas partes em cujo fauor se deram, para que com a requisitoria do vigayro faça ho juyz no condenado execuçam em seus beens como lhe parecer justiça" -Regimento dos officiaes \& pessoas que procuram no auditorio Ecclesiastico desta cidade ordenado pelo senhor Bispo de Coymbra, conde Darganil [Coimbra: João de Barreira e João álvares, depois de 15 de Fevereiro de 1547], fl. 4v. 
Gonçalo Pereira, bispo de Lisboa e coadjutor do arcebispo de Braga, deputado pela Sé Apostólica, por procuração lavrada em Lisboa, no dia 5 de Agosto de 1323, institui seu procurador a Egas Lourenço, cónego de Braga e do Porto, com poderes para receber rendas, exigir pagamentos, nomear alcaide, juiz e outros oficiais na cidade de Braga, que dele deviam receber o juramento e prestar homenagem, como se o dito D. Gonçalo presente fosse, compelindo com censuras eclesiásticas ou com o auxílio do braço secular todos os contraditores e rebeldes ${ }^{50}$.

Sem embargo, é compreensível que os magistrados a exercer funções no reino por delegação de competências da Sé Apostólica tivessem legitimidade para, à margem da intervenção do respectivo prelado, interpor o pedido de ajuda do braço secular perante o monarca. Para além dos acima referidos, $v$. g., em meados do século XV, o pedido dirigido a el-rei por D. Álvaro, bispo de Silves e juiz apostólico delegado, a propósito da contenda gerada em torno da nomeação do pároco da igreja de S. Miguel de Tresmiras (c. Vila Pouca de Aguiar), que pertencia à jurisdição eclesiástica do arcebispado de Braga, encabeçado por D. Fernando da Guerra $^{51}$; e o pedido feito a D. Afonso V pelo bispo auxiliar, D. Gil -nomeado por Sisto IV, em 12 de Junho de 1472-, contra a esposa do Doutor Pedro Afonso, citada por carta de 18 de Fevereiro de 1477, a comparecer na Corte no prazo de vinte dias ${ }^{52}$.

Nem mesmo a Ordem do Hospital prescindia deste mecanismo legal de ajuda. Por isso, o seu prior solicitou sucessivas confirmaçōes gerais para que, "em ajuda de braço sagral', as justiças régias mandassem executar as suas sentenças e mandados, prendendo os sentenciados e sequestrando os seus bens. A primeira dessas cartas foi solicitada por D. frei Álvaro Gonçalves Camelo a el-rei D. João I, que lha concedeu em Viseu, no dia 20 de Dezembro de 1409. De seguida, um alvará do infante D. Duarte, de 8 de Fevereiro de 1420, impôs a todos os corregedores, juízes e justiças "que se uos per dom frei nuno gonçaluez prior do espital ou pella sua parte forem dadas ou mostradas alguumas Sentenças ou cartas ou mandados que ell de ou mande que perteeençam a sua hordem e regimento dos caualleiros e freires della que uos lhe obedeçaaes e cumpraaes e dees a execuçam segundo em ellas for comtheudo por quanto mercee he delRey meu Senhor seer lhe assi fecto". Ainda nesse ano, por carta régia de 27 de Agosto, el-rei concedeu ao dito prior, D. Nuno Gonçalves de Goios, o mesmo privilégio. Os três documentos foram confirmados por D. Afonso V, em Évora no dia 5 de Abril de 1452, a pedido e apresentação do coevo prior da Ordem do Hospital, D. João de Ataíde ${ }^{53}$.

Como não há regra de Direito sem ressalva, mormente no lapso cronológico da Idade Média, surge um documento, datado de 16 de Julho de 1475, a indiciar uma partilha de competências da Coroa com a Casa de Bragança, a jurisdição senhorial laica que, em muitos aspectos, ombreava com a do próprio monarca. Trata-se de uma carta do cónego João Ferraz, bacharel em Decretos e vigário-geral do arcebispo de Braga, D. Luís Pires, pedindo auxilio de braço secular ao ouvidor

\footnotetext{
${ }^{50}$ Braga, AD - Colecção Cronológica, doc. 371.

${ }^{51}$ Marques, José, O recurso à justiça secular no século XV, cit. (n. 20), pp. 104-108.

52 Marques, José, A Arquidiocese de Braga no Séc. XV (Lisboa, 1988) pp. 438-439.

53 Lisboa, IAN/TT - Leitura Nova, Liv. 11 (Odiana, Liv. 3), fls. 189v-190v.
} 
das terras do duque de Bragança, João Vasques da Fonseca, e aos juízes de Chaves para, "segundo a continencia e forma das hordenaççooees deste reyno", prender e mandar prender Dinis Eanes, abade de São Nicolau de Carrazedo de Montenegro (c. Valpaços), que andava excomungado ${ }^{54}$. No entanto, este poderia ser um dos casos em que o monarca concede um apoio secular em geral, como os cedidos por D. João I e D. Duarte ao coevo arcebispo de Lisboa -acima referenciados- ou, $v$. g., o que concedeu D. Manuel I ao arcebispo de Braga, por carta outorgada em Alcochete no dia 25 de Junho de 1508, que lhe permitiria interpelar directamente aos "nossos corregedores juizes, justiças das comarcas dantre douro e minho e traslos montes e aos ounidores do Duque meo sobrinho e do marques de villa Real meu primo nas ditas comarquas ${ }^{\text {} 5}$. As ressalvas à legitimidade processual activa incluem, sem surpresa, o abade de Alcobaça $a^{56}$.

\section{IV. ÂMBito Material}

A ajuda de braço secular só deveria ser concedida em última instância, quando a Igreja não tivesse "outras armas para proceder", seguindo os procedimentos legais estabelecidos. E mesmo assim, nas Constituições Sinodais de D. Justo Baldino, de 1482, ficou registado um normativo canónico de Ius proprium contra os pedidos abusivos $^{57}$.

Nos finais do século XIII e princípios do seguinte, as disputas geradas em torno do Direito de padroado das igrejas seriam um dos casos mais paradigmáticos que coagia, assiduamente, o poder prelatício a recorrer à ajuda do braço da justiça de el-rei - v. g., os supra referidos documentos de 6 de Novembro de 1293 e de 5 de Maio de 1312, bem como a sentença de 18 de Maio de 1458-. Na concordata entre D. Dinis e a Santa Sé, assinada em Roma, no dia 12 de Fevereiro de 1289, queixa-se o clero luso de o monarca não convir devidamente ao pedido de ajuda de "braço sagral" contra a força que alguns padroeiros movem contra as liberdades da Igreja; os procuradores do monarca refutam a acusação e respondem que el-rei "dá seu poder contra aquelles que fezerem torto nas davanditas cousas; e quando for chamado dallo-á assy como o direito quer" (OA 2, 1, 20). O bispo do Porto, D. Frei Estêvão, em carta de 23 de Agosto de 1313, dirigida ao cónego e ao porcionário da sua igreja-Martinho Vasques e Domingos Martins, respectivamente- determinalhes que ponham éditos na igreja de Cedofeita sobre a eleição e confirmação de

${ }^{54}$ Marques, José, A Arquidiocese de Braga no Séc. XV, cit. (n. 51), pp. 474-475; Marques, José, $O$ recurso à justiça secular no século XV, cit. (n. 20), pp. 96-97.

55 Braga, AD - Rerum Memorabilium, III, fls. 95-95v.

56 Ventura, Margarida Garcez, Igreja e poder no século XV, cit. (n. 5), pp. 566-567.

57 "Item, estabelecemos e mandamos que, quando quer que alguma pessoa aa nosa instancia hou de alguum houtro for chamado a juizo presente nós hou nosso vigairo e chamar ajuda do braço secular hou outro poder pera aver favor que a justiça nom aja logar pera seer punido como ho direito quer, se for beneficiado seja privado do beneficio e se nom beneficiado seja sospensso da execuçom das hordeens por huum anno e seja aalém desto condenado por cada vez que o fezer em trezentos reaes desta moeda e a meetade seja aplicada pera a fabrica desta igreja e ha outra pera nossa chancellaria", em Synodicon Hispanum II. Portugal, edicion critica dirigida por Antonio García e García, Biblioteca de Autores Cristianos (Madrid, 1982), pp. 447-452 (449). 
D. Gonçalo Pereira para abade da referida igreja, visto ele ter verificado que ele a pode licitamente receber, e manda que deem posse ao referido D. Gonçalo ou a seu procurador, defendendo-o dos contraditores com censuras ou, se necessário for, recorrendo à ajuda do braço secular ${ }^{58}$.

O gladius ecclesiasticus esteve sempre obrigado a recorrer à ajuda do gladius secularis nos chamados casos de "justiça de sangue", que fazia parte da justiça maior de el-rei. É o que se pode inferir, $v$. $g$., de um documento régio outorgado no dia 13 de Maio de 1316, no âmbito do litígio entre o concelho e o bispo do Porto, em que este alega a ilegitimidade judicial do monarca com a doação feita pela rainha Dona Teresa - de 18 de Abril de 1120-, mas D. Dinis deixou bem claro que "posto que doaçom podesse seer, que por ella pareçia que nom qujs dar nem tolher dessy as apellaçoooes nem a justiça do sanguy, nem outra jurdiçom e jus Real, nem outra justiça mayor, mais per ella pareçia que as rreteue para ssy e que lhe nom deu al, saluo as rrendas da ujlla per termos sabudos" 59 .

A reserva das execuções de sangue à justiça de el-rei (a que estava obrigada a recorrer a justiça eclesiástica) surge exemplarmente consagrada num comentário que, a propósito do título "dos hereges", caiu da pena do compilador oficial das Ordenaçôes de 1446: "E vista per nós a dita ley, declarando acerca della dizemos, que pero o conhecimento de taaes feitos pertença principalmente aos Juizes Ecclesiasticos, os quaaes os devem julgar segundo acharem per direito, quando elles alguuns Ereges condapnarem per suas sentenças, porque a elles nom cabe fazerem taaes eixecuçoóes, por serem de sangue, devem remeter a nós os ditos condapnados com os processos, que contra elles forem hordenados, e sentenças, que contra elles derem, e nós mandaremos aos nossos Desembargadores da Justiça, que vejam os ditos processos, e sentenças, e as cumpram, e eixecutem assy como acharem per direito. E esto mandamos assy fazer, porque ouvemos certa enformaçom por leterados da nossa Corte, que assy he estabelicido per Direito Canonico, e Civil, e de longamente assy foy usado, e praticado em estes Regnos em tempo dos Reyx, que ante nós forom, e per nós ataa o presente" (OA 5, 1, 5).

Em suma, a ajuda do braço secular justifica-se "porque a iustiça da igreia não he rezão que cometa prender onde lhe parecer que poderia auer resistencia ou euidente perigo de morte ou feridas antes de direito se deue socorrer a justiça secular"; e, para além de prisões, o braço secular é chamado para executar as penhoras: "e assi o faze compryr nas penhoras que nos ditos dom abbades e dom priores e clerezia do dito arcebispado mandarem o dito Arcebispo e seus vigarios fazer de qualquer qualidade que seia assi per sentenças que contra elles seiāo dadas como por não comprirem as cousas que por bem de suas visitaçôes lhe forem mandadas fazer" ${ }^{\prime \prime}$.

A maior intervenção coercitiva do braço armado da Justiça de el-rei verifica-se, sem dúvida, nas prisões e cobrança das respectivas sanções pecuniárias dos excomungados $-v$. g., no caso $16^{\circ}$ da referida lei de D. Dinis consta que "Se alguum

58 Braga, AD - Colecção Cronológica, doc. 286.

59 Corpus Codicum Latinorum et Portugalensium eorum qui in Archivo Municipali Portucalensi asservantur antiquissimorum iussu Curiae Municipalis editum (Porto, 1891), I, pp. 55-56.

${ }^{60}$ Braga, AD - Rerum Memorabilium, III, fls. 95-95v. A propósito da oposição movida às visitações, $c f$. VenturA, Margarida Garcez, Igreja e poder no século XV, cit. (n. 5), p. 565; Marques, José, A Arquidiocese de Braga no Séc. XV, cit. (n. 51), pp. 530-534. 
creligo he escomungado per seu bispo E o creligo despreça a escumunham E nom quer sair della el Rey aa pitiçom do bispo pode E deue-o constranger $E$ poer-lhe pea que saJa da escomunham" ${ }^{1}$-. "A execução das penas temporais impostas aos excomungados -assevera Garcez Ventura- é uma das situaçōes que junta mais protestos quanto ao modo de colaboração de ambas as justiças" ${ }^{62}$. A autora elenca uma série de casos materialmente passíveis de recurso à ajuda do braço secular que vão de encontro ao aqui explanado, muito embora algumas situações por ela colacionadas me deixem sérias dúvidas se deviam ser incluídas nesta peculiar colaboração entre os poderes eclesiástico e régio, convencionalmente identificada como braço secular. A colaboração entre esses poderes não se esgota neste mecanismo, exigindo particular cuidado a análise de eventuais conjunturas analógicas e interpretaçōes extensivas.

\section{EFeitos Jurídicos}

Num dos capítulos apresentado pelo clero às Cortes de Elvas, reunidas em 1361, a resposta de D. Pedro I é categórica: “e ao que dizem, que quando demandam as minhas Justiças em ajuda do braço sagral pera fazerem direito, que o nom querem fazer; mandamos que o façam pela guisa, que de direito som theudos com aguisado" (OA 2, 5, 14). Mas a característica falta de coercibilidade do Ius canonicum ressuma de outra queixa, apresentada pelo clero à mesma reunião parlamentar, contra as justiças laicas que, ao domingo e em dias de festa, contra o Direito canónico faziam concelhos e audiências, sobretudo de feitos crime, no espaço sagrado dos adros e igrejas. Os prelados procediam contra eles por sentenças de excomunhão, mas a verdade é que eles "nom as queriam guardar, ante diziam palavras de desprezo da Santa Igreja, que lhes era d'escusar, a saber, que escumunhom nom brita osso, e que o vinho nom amarga ao escumungado" (OA 2, 5, 31).

Para obstar a que os condenados pelas justiças eclesiásticas se deixassem andar em estado de excomunhão, sem temor das penas espirituais e sem se preocuparem em obedecer aos mandados e sentenças canónicas, D. Fernando, em Lisboa no dia 18 de Setembro de 1368, mandou promulgar uma lei com as sanções civis a aplicar pelo braço secular em ajuda do religioso. Mas antes de fazer uma breve súmula dos seus pressupostos normativos, vale a pena citar o incipit desta ordenação, que traduz uma interessante fundamentação legal trecentista da ajuda do braço secular: "Em nome de deus amen. Porque a todo Rey cathollico come braço da Santa eigreia perteeçe de fazer e mandar comprir e aguardar as suas sentenças que direitamente som dadas E fazer que os seos sujectos seiam obedientes a ellas nos casos que som de sua jurdiçom por seerem elles gardados da sanha de deus e de muytos dampnos e perigoos em que caaem per essas sentenças spiciallmente pella sentença descomunhom de que a santa Eigreia toma espada spiritual que corta a alma que he a melhor e mais nobre parte do corpo do homem husa contra os reuees desobedientes E como a nos dom fernando pella graça de deus Rey de portugall e do algarue seia certo e notorioo que muytos do nosso senhoryo per contentamento ou per negrigençia

${ }^{61}$ Ordenaçōes de D. Duarte, cit. (n. 26), p. 274.

${ }^{62}$ Ventura, Margarida Garcez, Igreja e poder no século XV, cit. (n. 5), p. 567. 
se leixam jazer nas sentenças descomunhom que em elles som postas E nom curam de sair dellas polla qual razom naçe na Eigreia de deus grande scamdallo e muytas uezes aconteçe que he embargado o seruiço de deus e o sacryfiçio que se ha de fazer E antre os outros xpristaãos de que deuem feer squyuados recudem grandes hodios e infamyas nas pessoas e grandes perdas nos seus direitos e nos outros autos lydemos que lhes per esso som embargados" (OA 5, 27, 3-8) ${ }^{63}$.

As directrizes normativas sancionadas por esta ordenação fernandina, quando efectivamente fosse concedida a ajuda do braço secular, podem resumir-se ao seguinte: (i) fixa prazo de nove dias para os que incorrem nessa pena canónica se absolverem; caso contrário, (ii) sejam presos e não sejam soltos até que se absolvam e paguem a pena fixada; (iii) por cada nove dias que andarem excomungados paguem três libras portuguesas (iv) esta execução suspender-se-ia se o excomungado tivesse apelado da decisão. Os dinheiros daí resultantes são divididos em três partes a distribuir e aproveitar da seguinte maneira: (a) uma terça parte vai para a fábrica da igreja catedral do bispado em que a sentença for dada; (b) outra terça parte para o hospital dos meninos enjeitados da cidade desse bispado, se não houver hospital seja para os outros hospitais desse bispado e se não houver hospital em todo o bispado seja para criar os meninos enjeitados dessa cidade e dos outros lugares do bispado; (c) a última terça parte fica para os cofres de el-rei. (iv) O dinheiro destinado aos meninos enjeitados ficaria em poder de um homem bom, designado por autoridade e mandado das justiças desses lugares; $(v)$ o conhecimento das eventuais dúvidas sobre as excomunhões e respectivas penas, que possam resultar desta lei e ordenação, é do foro civil dos juízes ordinários das cidades e vilas onde os feitos e demandas se houverem de tratar e desembargar $(\mathrm{OA} 5,27,3-8)^{64}$.

No documento eclesiástico de Braga de 12 de Julho de 1410 -acima referido- ficou uma referência expressa ao pagamento de três libras por cada nove dias que andasse excomungado, indiciando estar a referir-se a esta lei de el-rei D. Fernando, da seguinte maneira: "chamandouos por esto em ajuda de direito com braço segral que prendades o dito pero Martinz onde quer que o achardes e o tenhades em bem preso e bem guardado e non o soltedes amtes de sobre <elo > auerdes recado da dita Eigreia de bragãa E de quantos noue dias achardes que andou e persseuerou na dita scomunhom tantas tres libras da moeda antiga leuade e auede del per sseus bens para sse destrebuirem e fazerem dellas o que mandado e hordinhado he na ley e ordinhaçom de nosso senhor Elrey sobre esto feita" ${ }^{65}$.

Posterior a esta data deve ser a lei de D. João I, a seguir compilada no mesmo título das Ordenações de 1446 -com referência à Lei dos reis antecessores-que em vez das três libras aplicadas pela lei de 1368 fala em sessenta soldos ${ }^{66}$-vinte soldos

${ }^{63}$ Braga, AD - Colecção Cronológica, doc. 902; Braga, AD - Rerum Memorabilium, vol. 3, fl. 89 .

${ }^{64}$ Braga, AD - Colecção Cronológica, doc. 902; Braga, AD - Rerum Memorabilium, vol. 3, fl. 89. Ventura, Margarida Garcez, Igreja e poder no século XV, cit. (n. 5), pp. 494-495.

${ }^{65}$ Braga, AD - Gaveta 2a das Propriedades do Cabido, doc. 48.

${ }^{66}$ A sanção pecuniária de sessenta soldos consta num capítulo apresentado às Cortes de Elvas de $1361\left(\mathrm{OA} 2,5,28^{\circ}\right)$. 
por cada libra-, repartidos da seguinte forma: (i) vinte soldos para o Hospital dos meninos; (ii) vinte soldos para a fábrica da igreja onde os excomungados fossem fregueses; (iii) e os restante vinte soldos para o rei, que ficariam para os alcaides do lugar onde o caso acontecesse. Mas tendo em conta que "pollo mudamento da moeda ${ }^{67}$ as dictas penas dos sessenta soldos se tornam tam pequenas, que [...] os escomungados nom querem sair das escomunhoöes com temor de tam pequenas penas", foi feita a equivalência de uma libra para quinze libras da nova moeda. Passando os nove dias de excomunhão a ser sancionados à taxa legal de quarenta e cinco libras, das quais se deveria fazer o "que se soya de fazer dos dictos sessenta soldos da dita moeda antigua" (OA 5, 27, 12-13) ${ }^{68}$.

Como o documento de 1410 ainda aplica a pena das três libras, parece manifesto que esta ordenação de D. João I seja posterior. Mas o terminus a quo ainda pode ser avançado, tendo em conta que uma das chamadas leis jacobinas (1418/1419) refere a sanção pecuniária compulsória dos excomungados no montante de sessenta soldos da moeda antiga: "Item achamos nos livros dos reis que ante nos forom e foy pellos prellados pedido em cortes que alguuns asy clerigos come leigos se taaes andassem scomungados e nom quisesem sair das scomunhóes que forem presos per as nossas justiças e levasem delles as penas come de scomungados. scilicet. Cada nove dias sesenta soldos da moeda antiga do dia que forem scomungados ataa que sayam da dicta scomunhom e nos porque o assi achamos e os reis dante nos sempre o fezerom e ahinda mais que os douctores dos canones teem que asi se deve de fazer portanto mamdamos aos nosos alcaides e a todallas nossas justiças que asi o façam comprir e aguardar" ${ }^{69}$.

Em suma, o principal efeito da ajuda prestada pelo gladius materialis é o de aplicar as penas temporais, nos casos em que as penas espirituais não surtiam o desejado efeito-"porque mal peccado os homeens mais soem de recear a pena temporal, que a sanha de Deos" (OA 5, 31, 4)-coagindo os contraventores e emprestando coercibilidade necessária às decisóes do foro eclesiástico. Nas encanecidas e sempre doutas palavras de Santo Isidoro de Sevilha (c. 560-636), seguindo o aforismo que veio a ser compilado para o Decreto de Graciano (C. 23 q. 5 c. 20), "Principes saeculi nonnumquam intra ecclesiam potestatis adeptae culmina tenent, ut per eandem potestatem disciplinam ecclesiasticam muniant. Ceterum intra ecclesiam potestates necessariae non essent, nisi ut, quod non praeualet sacerdos efficere per doctrinae sermonem, potestas hoc imperet per disciplinae terrorem" (Sentenças III, 51, 4).

\section{CONCLUSÃO}

A ajuda do braço secular, no caso português, a partir do século XIII converteuse num procedimento judicial muito peculiar, que pautava a relação de uma forma pacífica entre o poder religioso e o poder monárquico. Malogradamente,

${ }^{67}$ A equivalência da nova moeda já tinha sido feita nas Cortes de Braga de 1387, mas nesse parlamento entendeu-se que se deveria manter o valor das sançôes a pagar em caso de excomunhão (três libras/sessenta soldos).

68 Ventura, Margarida Garcez, Igreja e poder no século XV, cit. (n. 5), p. 495.

69 Ventura, Margarida Garcez, As "Leis Jacobinas", cit. (n. 7), pp. 20-21. 
existe uma enorme lacuna de informação para esta temática (o que não parece ser exclusivo de Portugal) e torna-se hoje praticamente impossível reconstruir todas as fases desse procedimento judicial. Sem embargo, uma réstia de esperança reside nos parcos subsídios escritos disseminados pelos pergaminhos coetâneos que conseguiram resistir à passagem dos séculos e chegaram até aos nossos dias.

Para além da efectiva positivação legislativa e da praxis judicial de antanho, a partir da análise feita ao instituto da ajuda do braço secular destilam inferências que merecem destaque pela notoriedade alcançada no recuo dos tempos. A primeira conclusão possível é de que a relação entre o poder temporal e o poder espiritual, durante a baixa Idade Média portuguesa, não foi sempre de constante litígio, antes pelo contrário, o mecanismo jurídico da ajuda do braço secular demonstra uma certa harmonia e distribuição de competências, uma inter-ajuda entre os dois poderes que tanto se digladiam como se complementam.

A importância deste mecanismo jurídico pode aferir-se, prima facie, pelo facto de fazer parte da chamada justiça maior de el-rei. Quer isto dizer que, em princípio, só o sumo representante do poder político poderia, mediante pedido formal, conceder esta ajuda à justiça da Igreja. Num tempo em que o privilegium fori era defendido de forma acérrima, torna-se compreensível que este mecanismo jurídico fosse tratado com todas as cautelas e com foros de reserva real. Esta relevância é levada ao extremo quando D. João II, em 1490, retirou esta faculdade ao tribunal supremo da Casa do Cível, sediado em Lisboa, e a concentrou no tribunal supremo da Casa da Suplicação, que acompanhava o monarca e a Corte itinerante nas suas deambulações pelo reino. Mas esta concentração de poder nas mãos de el-rei não impediram que se mantivessem e se confirmassem velhas prerrogativas como a outorgada, $v$. g., o prior da Ordem do Hospital em Portugal.

Em conformidade, também o pedido não estava ao alcance de quaisquer oficiais da justiça eclesiástica espalhados a esmo pelo território do reino. Ao que tudo leva a crer, o pedido de ajuda do braço secular só poderia ser formulado ao nível da cúpula pelos próprios prelados ou, então, pelos juízes com poderes delegados pela Santa Sé. A título de excepção, o pedido também poderia ser formulado pelo abade do mosteiro de Alcobaça.

Embora se destaquem âmbitos materiais como o da heresia, a Igreja podia recorrer a este auxílio laico sempre que alguém não acatava as suas decisões, feitas debaixo das correspondentes sanções espirituais. No entanto, este mecanismo só deveria ser movido em última instância e depois de esgotadas todas as sançôes eclesiásticas possíveis. Em suma, estando interdita a coercibilidade ou susceptibilidade de recurso à força por parte da Igreja, o poder jurisdicional eclesiástico carecia de um complemento a ser prestado por uma autoridade temporal, legitimamente investida de poder coercitivo, para fazer cumprir as suas ordens e sentenças judiciais imbuídas de sançôes meramente espirituais.

A rematar e sem embargo de melhor opinião, a ajuda do braço secular, no espaço geográfico e temporal definido para este estudo, não seria totalmente alheia à luta acesa entre as duas maiores instituições políticas da Idade Médiagladius Petri vs. gladius Caesaris- pelo domínio e primazia do poder. Por isso, este mecanismo prático e eficaz terá desempenhado, naqueles tempos, um especial 
papel no equilíbrio de poderes e talvez não seja despiciendo a sua relação com a teoria da separação constitucional de poderes, que constitui um dos dogmas das democracias contemporâneas. Deixando de lado os desafios hodiernos do Direito público, uma vez que o objecto imediato deste estudo é a Baixa Idade Média, fica aqui o repto final para um cotejo com o que de similar se teria passado em outros reinos e respectivos ordenamentos juspolíticos da Europa medieval.

\section{BiBLIOGRAFIA}

Albuquerque, Martim de, Portugal e a "Iurisdictio Imperii», em Revista da Faculdade de Direito de Lisboa, 17 (1964), pp. 303-353.

Albuquerque, Ruy de e Albuquerque, Martim de, História do Direito Português, (Ediçōes Pedro Ferreira, 2005), I.

Baвbitt, Susan M., Oresme's Livre de Politiques and the France of Charles V (Philadelphia, 1985).

BouzAda Gil, Maria Teresa, La Via de Fuerza: La Prática en la Real Audiencia del Reino de Galicia (Siglos XVII-XVIII) (Santiago de Compostela, 2001).

Branco, Maria João, Poder Real e Eclesiástico: A evolução do conceito de soberania e a relação com a praxis política de Sancho I e Afonso II (Tese de Doutoramento em História Medieval apresentada à Universidade Aberta, Lisboa, 2000).

Caetano, Marcello, A Bula Manifestis Probatum (Conferência proferida na Academia Brasileira de Letras Rio de Janeiro, 31-05-1979), in Marcello Caetano no exilio: estudos conferências comunicaçôes (2006), pp. 135-137.

Carvalho, Joaquim Ramos de, Jurisdição Eclesiástica, em Azevedo, Carlos M. (dir.), Dicionário de História da Igreja (Lisboa, 2001), III, pp. 41-43.

8. Centenário do Reconhecimento de Portugal pela Santa Sé (Bula"Manifestis Probatum" de 23 de Maio de 1179) Comemoração Académica (Lisboa, 1979).

Coelho, Maria Helena da Cruz, Bispos e Reis: oposiçôes em torno de bens e jurisdições temporais, em Lusitania Sacra, II/15 (Lisboa, 2003), pp. 279-287.

Costa, Adelaide Pereira Millán da, Comunidades urbanas de senhorio eclesiástico: a divergente experiência da cidade do Porto e de Braga, em Estudos em Homenagem ao Professor Doutor José Marques (Porto, 2006), I, pp. 77-85.

Costa, António Domingues Sousa, Mestre Silvestre e Mestre Vicente - Juristas da contenda entre Afonso II e as suas irmãs (Braga, 1963).

Costa, António Domingues de Sousa, Leis atentatórias das liberdades eclesiásticas e 0 papa Martinho V contrário aos Concílios Gerais, em Biblioteca Pontificii Athenaei Antoniani 19, Studia Historico-Ecclesiastica, Festgabe fur Prof. Luchesuius G. Spattling, O F. M. (Roma, 1977), pp. 505-592.

Domingues, José, As Ordenações Afonsinas - Três Séculos de Direito medieval (12111512) (Sintra, 2008).

Domingues, José, Dos Meirinhados às Comarcas Medievais Portuguesas, em Initium, 14 (2009), pp. 195-236.

Domingues, José, Exame Crítico às Leis de El-Rei D. Afonso III, em Direito: Revista da Universidade Lusíada do Porto, 7-8 (2013), pp. 185-223.

DuARTE, Luís Miguel, Um burgo medieval que muda de senhor. Episódios da vida do Porto medievo, Ler História 5 (Lisboa, 1985), pp. 3-16.

Duarte, Luís Miguel, Casa de Oração ou Covil de Ladrões (Notas sobre o direito de asilo 
em Portugal durante a Idade Média), em IX Centenário da Dedicação da Sé de Braga, Actas do Congresso Internacional, Vol. II/1 - A Catedral de Braga na História e na Arte (Séculos XII-XIX), Universidade Católica Portuguesa / Faculdade de Teologia - Braga Cabido Metropolitano e Primacial de Braga (Braga, 1990), pp. 617-645.

DuArte, Luís Miguel, Justiça e Criminalidade no Portugal Medievo (1459-1481) (Coimbra, 1999).

Figueiredo, Maria Amélia da Silva Alves dos Santos, A Administração Municipal do Porto entre 1488 e 1498 Segundo o Livro 6 de Vereações (Dissertação de Mestrado em História Medieval apresentada à Faculdade de Letras da Universidade do Porto, Porto, 1996) [disponível na internet: http://repositorio-aberto.up.pt/ handle/10216/18123].

Havet, Julien, L'Hérésie et le Bras Séculier au Moyen Âge Jusqu'au XIII Siècle (Paris, 1881) [disponível na internet: http://gallica.bnf.fr/ark:/12148/bpt6k66940c.r=.langPT].

LineHan, Peter, Two Marriage Cases from Medieval Iberia, em Zeitschrift der SavignyStiftung für Rechtsgeschichte. Kanonistische Abteilung, 83 (1997), pp. 333-341.

Logan, F. Donald, Excommunication and the Secular Arm in Medieval England, Studies and Texts, 15 (Toronto, 1968).

Marques, José, A Arquidiocese de Braga no Séc. XV (Lisboa, 1988).

MARQues, José, D. Afonso IV e as Jurisdições Senhoriais, em Actas das II Jornadas LusoEspanholas de História Medieval (Porto, 1990), IV, pp. 1527-1566.

Marques, José, D. Afonso IV e as Jurisdiçôes Senhoriais Galaico-Leonesas no Norte de Portugal, em Brigantia, 12/4 (Bragança, 1992), pp. 175-196.

Marques, José, Relaçôes entre a Igreja e o Estado em Portugal no século XV, em Revista da Faculdade de Letras - História, II/11 (1994), pp. 137-172.

Marques, José, O Senhorio de Braga, no século XV: principais documentos para o seu estudo, em Bracara Augusta, 46 (Braga, 1997), pp. 5-136.

MARQues, José, Igreja e Poder Régio, em A génese do Estado Moderno no Portugal TardoMedievo: Ciclo de Conferências (Lisboa, 1999), pp. 217-256.

MARQUES, José, $O$ recurso à justiça secular no século XV: um caso paradigmático, em Scientia Iuridica, LIV/301 (2005), pp. 89-111.

Marques, José e Cunha, Maria Cristina Almeida e, Conflito de jurisdiçôes e documentos judiciais: O caso de Braga, em Bracara Augusta, 50 (Braga, 2002), pp. 5-40.

Mattoso, José, A Cúria Régia de 1211 e o Direito Canónico, in Naquele Tempo. Ensaios de História Medieval, Obras Completas (2000), I, pp. 519-528.

Mattoso, José, Krus, Luís e Andrade, Amélia, A Terra de Santa Maria no Século XIII - Problemas e Documentos, edição da Comissão de Vigilância do Castelo de Santa Maria da Feira (1993).

Nogueira, José Artur Duarte, Lei e Poder Régio I. As Leis de Afonso II (Lisboa, 2006).

NogueIra, José Artur Duarte, Organização intermédia do Estado - séculos XIII e XIV. Uma perspectiva júris-historiográfica, em Estudos em Homenagem ao Professor Doutor Paulo de Pitta e Cunha (Coimbra, 2010), III, pp. 521-528.

Otero, Paulo, D. Afonso II e a Edificação do Estado: A raiz do Constitucionalismo Português, em Estudos em Homenagem ao Prof. Doutor Martim de Albuquerque (Coimbra, 2010), II, pp. 523-538.

PAIS, Álvaro, Espelho dos Reis I, Estabelecimento do texto e tradução do Dr. Miguel Pinto de Meneses (Lisboa, 1955).

PanATeri, Daniel, Las dos espadas y el vicariato divino en Siete Partidas, em Lemir, 19 (2015), pp. 265-280. 
PiCARDi, Nicola, La Giurisdizione All'Alba del Terzo Millennio, em Dialletica, Diritto e Processo, 3 (2007).

Pimenta, Alfredo, A bula "Manifestis Probatum" de Alexandre III, de 23 de Maio de 1179, in Subsidios para a História de Portugal: Textos e Juizos Críticos (Lisboa, 1937), pp. 27-37.

Poder Espiritual/Poder Temporal. As relaçôes Igreja-Estado no tempo da Monarquia (11791909), Actas do Colóquio, Academia Portuguesa da História (Lisboa, 2009).

Portugal: um estado de direito com oitocentos anos: bula Manifestis probatum de 23 de Maio de 1179 (Lisboa, 1981).

Prata, Jorge, A Jurisdicionalização do Poder: D. Afonso IV e o Chamamento Geral, em Revista de História da Sociedade e Cultura, 13 (Coimbra, 2013), pp. 103-130.

Prata, Jorge, Poder e Justiça no Reinado de D. Afonso IV (Dissertação de Mestrado, Faculdade de Letras da Universidade de Coimbra, Coimbra, 2013).

Saraiva, Anísio Miguel Sousa, A Sé de Lamego na Primeira Metade do Século XIV (1296-1349) (2003).

Silva, Nuno Espinosa Gomes da, História do Direito Português - Fontes de Direito 5 (Lisboa, 2011).

Silva, Nuno Espinosa Gomes da, Ainda sobre a lei da Cúria de 1211 respeitante às relaçôes entre as leis do Reino e o direito canónico, in Direito e Justiça Revista da Faculdade de Direito da Universidade Católica Portuguesa, 12/1 (1998), pp. 3-36.

SiLVA, Nuno Espinosa Gomes da, Sobre a lei da Cúria de 1211 respeitante às relaçôes entre as leis do Reino e o direito canónico, in Revista Jurídica, 1 (Lisboa, Dez./Maio 1973), pp. 13-19.

Ventura, Margarida Garcez, D. Duarte como árbitro do direito de asilo - um caso exemplar, em Actas das III Jornadas Hispano-Portuguesas de Historia Medieval - La Peninsula Ibérica en la Era de los Descubrimientos (1391-1492) (Sevilla, 1991), I, pp. 849-855.

Ventura, Margarida Garcez, Igreja e poder no século XV. Dinastia de Avis e Liberdades Eclesiásticas (1385-1450) (Lisboa, 1997).

VenturA, Margarida Garcez, Elementos para a compreensão da vigilância do rei sobre o seu reino: o beneplácito régio, em Poder Espiritual/Poder Temporal. As relações Igreja-Estado no tempo da Monarquia (1179-1909) (Lisboa, 2009), pp. 429-449.

Ventura, Margarida Garcez, As "Leis Jacobinas". Estudo e Transcrição, Medievalista online 12 (2012) [disponível na internet: http://www2.fcsh.unl.pt/iem/medievalista/MEDIEVALISTA12/ventura1203.html].

Ullmann, Walter, The Growth of Papal Government in the Middle Ages (2010).

Watt, J. A., Pouvoir Spirituel et Pouvoir Temporel, em Histoire de la Pensée Politique Médiévale 350-1450, sous la direction de James Henderson Burns (Paris, 1993)

\section{FONTES IMPRESSAS}

Censual do Cabido da Sé do Porto - Códice membranáceo existente na Biblioteca do Porto, edição de Joaquim Grave (Porto, 1924).

Chancelarias Portuguesas. D. Duarte (Lisboa, 1998), vol. I, Tomo 1.

Chancelarias Portuguesas. D. João I (Lisboa, 2006), vol. III, tomo 2.

Chancelarias Portuguesas. D. João I (Lisboa, 2006), vol. IV, tomo 1.

Corpus Codicum Latinorum et Portugalensium eorum qui in Archivo Municipali Portucalensi asservantur antiquissimorum iussu Curiae Municipalis editum (Porto, 1891), I. 
Decretales D. Gregorii Papae IX, Svae Integritati, vna cvm glossis restitvtae (Roma, 1582), Corpus Juris Canonici, [disponível na internet: http://digital.library.ucla. edu/canonlaw ].

Fragmentos de legislação escritos no livro chamado Antigo das Posses da Casa da Supplicação, em Collecção de Livros Ineditos de Historia Portugueza, dos reinados de D. João I, D. Duarte, D. Affonso Ve D. João II, publicados de ordem da Academia Real das Ciências de Lisboa, por José Correia da Serra, tomo III (Lisboa, 1793).

Martins, Ana Maria, Documentos Portugueses do Noroeste e da Regiāo de Lisboa. Da Produção Primitiva ao Século XVI (Lisboa, 2001).

Ordenaçoens do Senhor Rey D. Affonso V, Real Imprensa da Universidade (Coimbra, 1792) (fac-simile da Fundação Calouste Gulbenkian, Lisboa, 1984/1998).

Ordenaçôes Manuelina: Livros I a V: Reprodução em fac-símile da edição de Valentim Fernandes (Lisboa, 1512-1513), com Introdução de João José Alves Dias, Centro de Estudos Históricos da Universidade Nova de Lisboa (Lisboa, 2002).

Ordenaçoens do Senhor Rey D. Manuel, na Real Imprensa da Universidade (Coimbra, 1797) (fac-simile da Fundação Calouste Gulbenkian, Lisboa, 1984).

Ordenações de D. Duarte, edição preparada por Martim de Albuquerque e Eduardo Borges Nunes (Lisboa, 1988).

Regimento dos officiaes \& pessoas que procuram no auditorio Ecclesiastico desta cidade ordenado pelo senhor Bispo de Coymbra, conde Darganil [Coimbra: João de Barreira e João álvares, depois de 15 de Fevereiro de 1547].

Synodicon Hispanum II. Portugal, edicion critica dirigida por Antonio García e García, Biblioteca de Autores Cristianos (Madrid, 1982). 
